\title{
GABBR2 wt Allele
}

National Cancer Institute

\section{Source}

National Cancer Institute. GABBR2 wt Allele. NCI Thesaurus. Code C101482.

Human GABBR2 wild-type allele is located within 9q22.1-q22.3 and is approximately 421 $\mathrm{kb}$ in length. This allele, which encodes gamma-aminobutyric acid type B receptor subunit 2 protein, is involved in gamma-aminobutyric acid-mediated signaling. 